\title{
Modeling the Competitiveness of Indonesian Palm Oil Industry: A Conceptual Model Using Hierarchical Multi-Level System Approach
}

\author{
Roland Y.H. Silitonga ${ }^{1 *}$, Senator Nur Bahagia ${ }^{2}$, Tota Simatupang ${ }^{3}$, Joko Siswanto $^{4}$
}

\begin{abstract}
Indonesian Palm Oil Industry has the largest market share in the world, but still faces problems in order to strengthen the level of competitiveness. Those problems are in the industry chains, government regulation and policy as meso environment, and macro economic condition. Therefore these three elements should be considered when analyzing the improvement of competitiveness. Here, the governmental element is hoped to create a conducive environment. This paper presents the industry competitiveness conceptual model, using hierarchical multilevel system approach. The Hierarchical multilevel system approach is used to accommodate the complexity of the industrial relation and the government position as the meso environment. The step to develop the model firstly is to define the relevant system. Secondly, is to formulate the output of the model that is competitiveness in the form of an indicator. Then, the relevant system with competitiveness as the output is built into a conceptual model using a hierarchical multilevel system. The conceptual model is then discussed to see if it can explain the relevant system, and the potential of it to be developed into a mathematical model.
\end{abstract}

Keywords: Competitiveness, hierarchical multilevel system, value chain, palm oil industry.

\section{Introduction}

The transformation of the global economy has caused a strong competition among business units and industries in every country, including Indonesia, to gain global market share. The palm oil industry is one of the industries in Indonesia which has a high global market share. Since 2005 up to 2009, Indonesian market share has increased from $43 \%$ to $46 \%$. Even though, the Indonesian palm oil industry is still facing problems. Researches result (Said [21], Tambunan [29], also Simeh [24]) shows obstacles in the Indonesian palm oil industry, such as lack of technology savvy, uncoordinated government policy, poor investment regulation, lack of production input, inadequate infrastructure, lack of development in downstream industry which can create products with a high level of global competitiveness, also macro environment like complementer product price and environmental issues. Those problems are in the industry chain, government regulation and policy, and also the macro economic environment. Hidayat et al. [12] recommended that for palm oil industry it was necessary to define strategy to increase added value, while Hadiguna [11] gave policy recommendations necessarry to manage the palm oil supply chains risk.

\footnotetext{
1, Department of Industrial Engineering, Harapan Bangsa Institute of Technology, J. Dipati Ukur 80-84, Bandung 40132, Indonesia. 2,3,4Department of Industrial Engineering, Bandung Institute of Technology, Л. Ganesha 10, Bandung 40132, Indonesia

Email: roland@ithb.ac.id, senatornurb@yahoo.co.id

*Corresponding author
}

Some researches about the competitiveness of Indonesian palm oil industry have been done (Marks et al. [14], Tambunan [29], Rifin [19], Susila [27], Chalil [5], Akyuwen and Sulistiyanto [1] also Rifin [20]). Those researchers can be categorized into two. First are competitiveness researches focusing on the environment of both government's influence and international economic condition. Classifications of palm oil industrial environment are meso and macro (Siggel, [22]). Meso environment is a quasi-controllable national environment such as government regulation and policy. The macro environment is an uncontrollable international economic environment. Second are researches concentrating on production cost and income distribution received by stakeholders in the industry value chain. Both types of researches are still in partial state and not yet able to present the factors affecting competitiveness in an integrative way. In addition, Kaplinsky and Morris [13] shoulded that competitiveness shoud be observed systemically. The complete, existing value chain should be analyzed under the theme of increasing competitiveness and added value. This is also in accordance with Porter's statement [18] that to obtain competitive advantage, value chain should be arranged as a system instead of separated elements. Thus, it is necessary to utilize a value chain approach in defining the system, counting along the chains relation within this industry, also the influence of macro and meso environment concurrently. This idea aligns with the research of Martin et al. [15] that reveals competitiveness is highly dependant to controllable factors by the government and companies also uncontrollable factors by internatio- 
nal economic condition. Based on that, there is a need to improve the competitiveness of Indonesian palm oil industry, by considering not only the value chain, but also meso environment and macro environment.

Hierarchical multi-level system (HMLS) approach is chosen based on two things. First, the model should accommodate the influence of international market and government, also the interaction between actors in each chain. Second, the model should describe the role of government in giving the regulation to support the competitiveness of the industry. This role is very important in risk management for palm oil industry (Hadiguna [11]). The regression models which have been used in the previous researches (Rifin [19, 20], Akyuwen and Sulistiyanto [1]) were not able to accommodate it. HMLS have the ability of independent subsystem decomposition, hence the role of actors in subsystem levels can be described. Beside that, its structure can put the government in the right position as the supremal unit or coordinator of the industry.

The purpose of this paper is to present a conceptual model that can describe and accommodate the value chain which is influenced by government policy and regulation and macro environment, to improve competitiveness. The rest of the paper is organized as follows. First, the hierarchical multi-level system and its application is discussed. Second, the components of palm oil industry as the relevant system are explained. After that, there is discussion about the industry competitiveness indicators before it is used for the conceptual model. The conceptual model is built based on the relevant system by using the hierarchical multilevel system approach. The model is then discussed and concluded.

\section{Methods}

\section{Hierarchical Multilevel System}

Mesarovic et al. [16] developed the hiapproachl multilevel system approachl multilevel system approach. The hierarchical multilevel system is a representation of organization model with vertical arrangements of subsystems which comprise the overall system, and there is priority of action or right of intervention of the higher level subsystems, and dependence of the higher level subsystems upon the actual performance of the lower levels.

There are three types of hierarchy, namely strata, layer and echelon. Strata arrange the hierarchy based on abstraction level. Layers arrange a hierarchy based on decision complexity. Echelons arrange the hierarchy based on the level of organization. A two echelon level system is diagrammed in Figure 1.

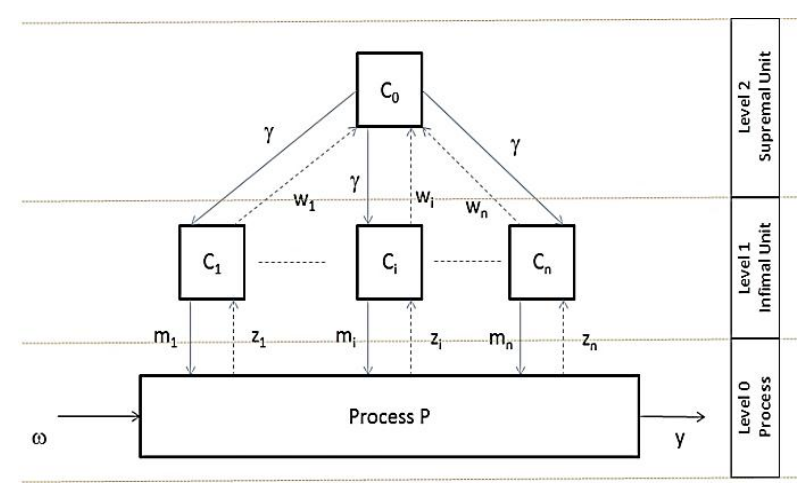

Figure 1. Two level hierarchical system

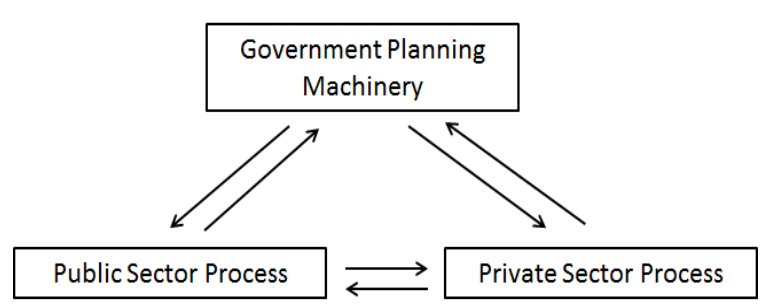

Figure 2. Main subsystems of the rural development system (Belshaw et al. [4])

There are $n+2$ elements: a process, $n$ infimal units, and a supremal unit. Unit $C_{0}$ is the unit with higher level which is called supremal unit. The supremal unit coordinates lower level units called infimal unit, $C_{i}$. The coordination is done by giving coordination input $\gamma$. Infimal unit control the process in the system by giving control input $m_{i}$. The feedback information is given from the process to the infimal unit, so then from infimal unit to the supremal unit. There is interdependence between levels, decision problem of infimal unit is dependent on supremal unit action vice versa. This is solved by a priority of action of the supremal unit.

The supremal unit coordinates the infimal units by giving intervention, whether it is pre-decision intervention or post-decision intervention, or by controlling the interaction between infimal units. The successful coordination is measured relatively in accordance with the supremal unit or overall objecttive function.

The hierarchical multilevel system is widely used to solve environmental a system such as water resources system (Haimes [9]), control system (Stoilov and Stoilova [25], Stoilova [26]), also a social system (Belshaw et al. [4]). The hierarchical multilevel system has advantages in decomposing complex systems into independent subsystems (Haimes [9]), and the decomposition enable researcher to consider the interest of decision maker in subsystem level (Haimes and $\mathrm{Li}[10]$ ).

The application of this approach to the social system is developed by Belshaw et al. [4]. The hierarchical multilevel system is used to formulate rural 
development system. The system is then used to develop a conceptual framework for designing effective rural development program. The research model consists of three main subsystems (Figure 2). The higher level subsystem is planned, the lower level subsystems are processed.

The outputs of research are, first, a hierarchical planning and control formulation of the rural development system and second, a program activity scheme. The formulation and scheme are then applied in the rural development in Kenya. The advantage of the approach is that the emphasis is placed on the rural system itself rather than on the planning documents. The hierarchical formulation enables the planners to appreciate the relationship between the control inputs, the plan implementation procedures, the performance of the subsystems as well as the performance of the overall rural system

\section{Building Relevant System}

In order to improve the competitiveness and added value, the existing value chain needs to be analyzed systematically (Silitonga and Nur Bahagia, [23]). Figure 3 shows the relevant system of Indonesian palm oil industry. Using this, all of the obstacles previously stated can be mapped.

One of the outputs from this relevant system is crude palm oil (CPO) that could either be exported or sold domestically to undergo further processes of refined palm oil (RPO) becoming cooking oil and other derivatives.

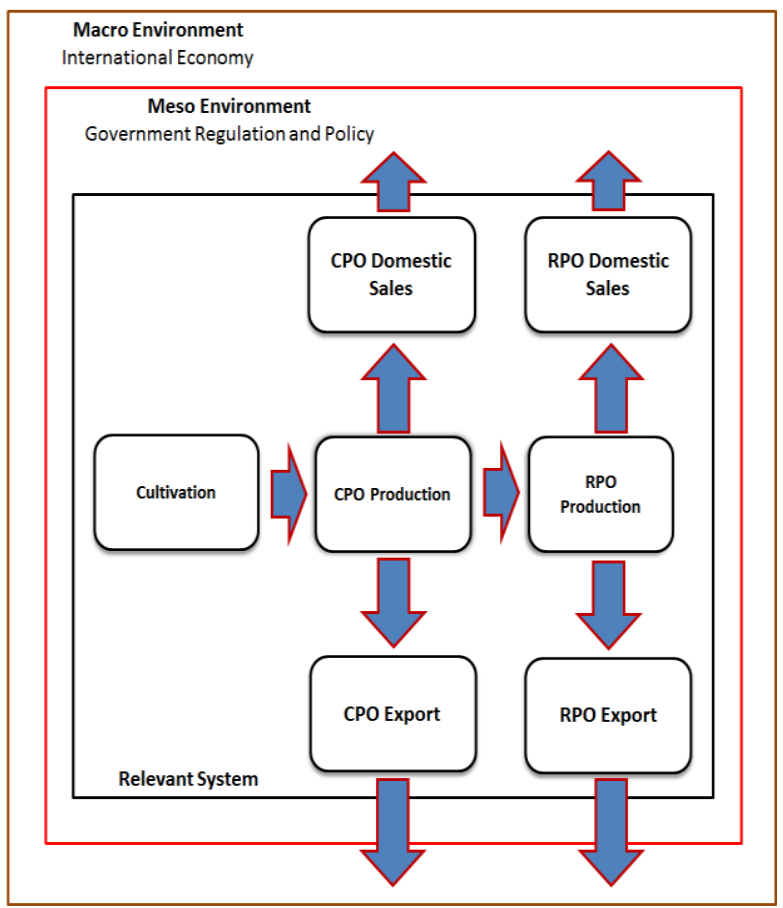

Figure 3. Relevant system
Cooking oil is a crucial domestic necessity, thus the existence of export taxed for this commodity (Rifin [20]). Indonesia's production has exceeded the domestic needs. Domestic palm oil usage percentage has dropped through the last decade, from $27 \%$ in 2005 to $24 \%$ in 2009 (BPS [3]). Meanwhile, CPO consumption to be further processed into RPO will increase added value, which will also influence competitiveness in palm oil industry. Therefore, attention is necessary for RPO proportion in the whole export commodity of palm oil. In order to keep the system simple, the further downstream derivatives will be limited to RPO.

Viewing the relevant system above, we can find main producers of fresh fruit bunch in this market share: smallholders (petani mandiri, PM), government-owned companies (PTPN) and private companies (perusahaan besar swasta, PBS). The following are the production share data: PM 36\%, PTPN 12\%, PBS 52\% (BPS [2]). Each of them has different productivity. Also PBS and PTPN have facilities to produce and sell CPO an RPO.

The relevant system also has the role of government as regulator, represented by the relevant ministry for each phase. For cultivation and CPO processing, policies are issued by the Ministry of Agriculture. In the next subprocess, the production of RPO (and other derivatives), policies are issued by the Ministry of Industry. In trading, both domestically and for exporting, policies are issued by the Ministry of Trading and the Ministry of Finance. Various policies issued can be either advantageous for one particular stakeholder but on the other hand disadvantaging the other, which will affect the competitiveness of the palm oil industry as a whole. In 2010 the government, Ministry of Industry in particular, has issued PP 13/2010. The regulation will support the downstream products which have more added values. By increasing the added value, it will also increase competitiveness (Martin et al. [15]), compared to conservative strategies implemented all this time in the form of extensification (Widodo et al. [30]) and intensification (Rifin [19] and Sa'id [21]). The relevant system also depicts an international environment that considers the macro environment for palm oil industry. International condition commonly described through global demand (Susila [27] and Fagerberg [7]), currency (Siggel [Error! Reference source not found.] and Rifin [19] and Susila [27]) and the influence of palm oil substitutive products in international market such as soybean oil (Akyuwen and Sulistiyanto [1], Simeh [24], also Susila, [27]).

\section{Industry Competitiveness Indicator}

The competitiveness concept has been developed starting from product level, company, network or 
chain (industry level) up to nation level. At network and nation level some of the definitions will be presented. According to World Economic Forum [31], competitiveness is a group of institutional, policy and other factors which determine the productivity level of a country. Competitiveness is the level where a country is able to, in free and fair market condition, produce the products or services to fulfill world's demand, and also preserve and increase people's income in a long term (European Commission [6]). Competitiveness is also defined as a capability indicator to manufacture products and services in a suitable, or even lower, price compare to others, while gaining payment profit from the used resource (Frohberg and Hartmann, [8]). Porter [18] stated that competitiveness is an ability to create products or services which can give more added value than competitors' products. This fact will be reflected in the sales and profit improvement. Martin et al. [15] defined competitiveness as a sustained ability to profitably gain and maintain market share. By looking at these definitions, it can be concluded that competitiveness is a sustained ability to maintain even increase market share and added value. There are two indicators here to be considered, market share and added value.

\section{Conceptual Model}

Based on relevant system and competitiveness as the output, the conceptual model of Indonesian palm oil industry can be developed using a hierarchical multilevel system. The model is presented in Figure 4. It is a two echelons hierarchical system. At the process level all big activities in the value chain to produce and sale CPO and RPO are arranged. The model consists of seven sub-processes: cultivation, $\mathrm{CPO}$ and RPO processing, and sales, domestic and export. In the process level there will be physical flow from the free fruit bunch, transported and transformed into CPO, some of them will be exported; some of them will be further transformed into RPO, and then sold. At the next level (level 1) there are the owners of the processes, which are PM, PBS, PTPN, CPO exporter and RPO exporter. PM control (do) cultivation process only, while PBS and PTPN control all the subprocesses including export. There are also traders who buy the CPO and RPO for export purpose. At the highest level of hierarchy (level 2) there is government. The relation between the industry actors and the government is hierarchical, because the government is trying to coordinate the industry by using policy and regulation as coordination inputs to increase competitiveness. There are physical, information and money flows between chains and stakeholders. The physical flow is used to determine market share, while money flow is important for value added.
The inputs to the process can be divided into two categories. First, the exogenous input from international market and economic such as world demand, value exchange and effect of substitution products of palm oil in international market, such as soy oil. Second, the endogenous input from actors to control their processes. The output of this system is competitive which is measured by market share and added value. Indonesian market shares can be determined by comparing the export to total world export. Meanwhile the added value can be determined using the export price comparison. It is important to note that $\mathrm{RPO}$ has a higher added value than CPO.

\section{Results and Discussion}

The conceptual model is constructed to help the government define an optimum policy and regulation. The model simulates the effect of a regulation before implementation. Hence there is a need to construct a mathematical model. It is then important to consider the form of the mathematical model, and the variables involved.

The lowest element of the hierarchy in figure 4 is the process, P, which consists of seven subprocesses. Based on Mesarovic et al. [16], the process P (see Figure 1) is a mapping

\section{$P: M \mathrm{x} U \mathrm{x} \Omega \rightarrow Y$}

It is the mapping of $M$ (set of control input $m$ ) and $U$ (set of coupling $u$ ) also $\Omega$ (set of disturbance input $\omega$ ) to produce $Y$ (set of subprocesses output $y$ ). If this is applied to the conceptual model, for every subprocess output $y_{i}$ at period $t$, the relation of $m, u, \omega$ and $y$ will be

$y_{i t}=\omega_{i t} u_{i t} \sum_{j=1}^{n}\left(1+m_{i j t}\right) F_{i j t}$

where $i$ is subprocess index and $j$ is the actor (infimal units) index. Variable $F_{i j t}$ is the basic function of each subprocess. For example, in the cultivation subprocess, it is the production as a function of cultivation area and productivity per area. The coupling variable $u$ can be in the form of output $y_{i-1}$ from the previous subprocess. The disturbance to the system $\omega$ is from the macro environment which is the international economic condition. The International economy condition is generally described as world demand, value exchange (Rifin [19], Siggel [22], and Susila [27]) and effect from substitution products of palm oil in international market, such as soy oil (Susila [27]), Simeh [24], and Akyuwen and Sulistyanto [1]).

The characteristic of the model is dynamic, and there is a level of uncertainty caused by disturbance input 


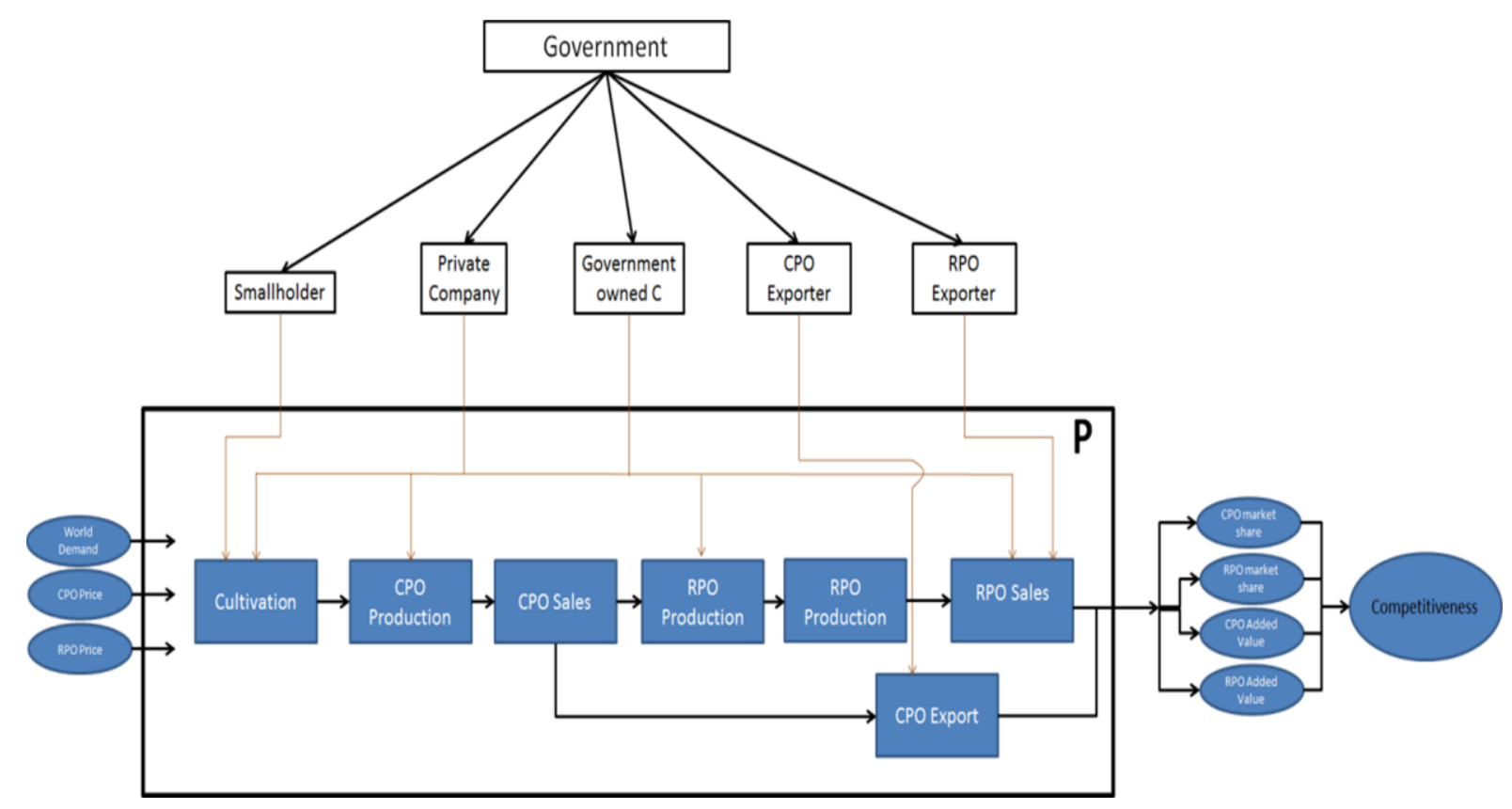

Figure 4. The conceptual model of palm oil industry

from macro environtment. Hence the model can use on-line coordination (Mesarovic et al., [16]) to improve overall performance, rather than obtain an optimal overall performance, which in this case is competitiveness. It means that recent competitiveness will be improved for the next period by putting new coordination input which in this case is changes of regulation or policy. The change of coordination input and disturbance inputs will make the actors to revise the control input accordingly. Based on the hierarchical multilevel approach, related variables can be divided into five categories, control inputs, coordinating inputs, and feedback information, disturbances from the environment, and outputs which can be measured by performance function.

Control inputs $m$ is given by the infimal units to the subprocess and the form will depend on the subprocesses. In the cultivation process, the inputs will be productivity and farm extension, in the production of CPO and RPO will be the target of production, and for the exporters is the amount of money obtained. Based on [16], control input is a function of feedback and coordination input

$m_{i}=f\left(z_{i}, \gamma_{1}\right)$

Where $m$ is the control input, $z$ is the feedback to the infimal units and $\gamma$ is the coordination input. In this model $z_{i j t}=y_{i t-1}$, it means the feedback to the infimal unit is the previous output of the subprocess. The application of the model will be

$m_{i, j, t}=a_{i j} \gamma_{i, t}$ for $y_{i t-1}<y_{i t-2}$;

$m_{i, j, t}=b_{i j} \gamma_{i, t}$ for $y_{i t-1} \geq y_{i t-2}$ where $y_{i t-1}$ is the output of process $i$ at stage $t-1$, and $\gamma_{i t}$ is the coordination input to subprocess $i$ at stage $t$, and $a$ and $b$ are conversion variables.

All the infimal units (actors) are coordinated by supremal unit (government). The Government will give coordination inputs $\left(\gamma_{i t}\right)$ in the form of regulation and policies, such as tax, financing programs, incentive etc, based on the system performance. Coordination input is a function of system performance $G$

$\gamma_{i t}=f\left(G_{t}\right)$

where $G_{t}$ is the feedback to the supremal unit in the form of performance function. It can be an index composed by international market share and added value of CPO and RPO. This is the performance function of the industry itself. Mesarovic et al. [16] define performance function $\mathrm{G}$ as a function of process outputs. In the discussed model the performance function which is the competitiveness index will become

$G_{t}=\alpha\left(y_{6 t} / W_{C P O}\right)+\left(y_{7 t} / W_{R P O}\right)$

The increasing $G$ indicates an increase in competitiveness. $W_{C P O}$ and $W_{R P O}$ are the total world exports in a period. Factor $\alpha$ is an added value comparison factor of CPO and RPO. This comparison factor is also a weight. RPO has higher added value compared to CPO, hence $\alpha$ will always be smaller than 1. This will make the contribution of CPO market share lower than RPO in increasing competitiveness. The difficulty in getting added value data 
can be minimized if we use CPO and RPO price as the representation of subsequent added value. It is important to note that equation (6) can be easily extended to accommodate downstream products.

A simple example of the application is given using actual data. The model is applied to predict the export of Indonesian CPO and RPO of 2005 up to 2010. Table 1 shows the set of variables applied to the model. The disturbance inputs are all set to zero. All control inputs $m$ is also set to zero. The coordination inputs are only export tax $3 \%$, applied to the subprocess CPO and RPO export, at all periods. If we set all the control inputs and coordination inputs (except tax) to be zero all the time, also the actual disturbances are small so it can be neglected, then we can assume that the model becomes a prediction model. The value comparison factor $\alpha$ is set to be 0.96 . In order to determine the basic function $F_{i j t}$ we use BPS data of 1999 up to 2004. The average export price of $\mathrm{CPO}$ and $\mathrm{RPO}$, also the total world export is taken from COMTRADE data.

Using the set of those variables, the export of Indonesian CPO and RPO can be obtained. The export of $\mathrm{CPO}$ and RPO can be calculated using equation (2). For RPO export, the value of $u$ is calculated using Table $1, u_{7}=y_{4 t}-y_{5 t}$, which is the subtraction of national production of RPO by domestic sales of RPO. The national production of RPO is influenced by the domestic sales of CPO $\left(y_{3 t}\right)$, while the domestic sales is influenced by domestic consumption, mostly for cooking oil and a small to be further processed into downstream product. The use of RPO to be processed into a downstream product have shown an increasing trend, however more investment is needed in the future.

Table 1. Variables in subprocesses

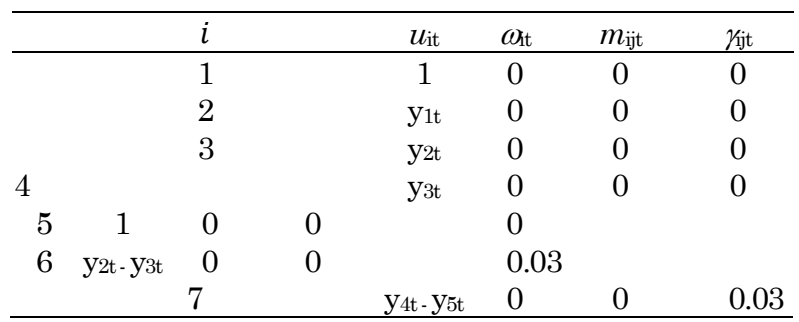

Table 3. Competitiveness index

\begin{tabular}{cccc}
\hline Year & G (model) & G (actual) & G (Malaysia) \\
\hline 2005 & 0.877 & 0.983 & 0.763 \\
2006 & 0.864 & 0.951 & 0.807 \\
2007 & 1.013 & 0.950 & 0.736 \\
2008 & 1.119 & 1.149 & 0.797 \\
2009 & 0.993 & 1.046 & 0.730 \\
2010 & 1.132 & 1.066 & 0.855 \\
\hline
\end{tabular}

The export of Indonesian CPO and RPO are presented in Table 2. The results of the model are compared with actual export in 2005 up to 2010. It can be seen that mostly the errors are below $10 \%$ and there is no trend that the errors increasing or decreasing. The errors are acceptable, since all disturbances are assumed to be zero. If we want to increase competitiveness, we have to increase RPO export. Table 2 show that the proportion of CPO export is still dominating, so government has to give such policy to reduce it and increase RPO export.

By using the CPO and RPO export, we can calculate the calculation of competitiveness index $G$. The results are presented in Table 3. Here the competitiveness index using the model is compared with actual conditions. There are slight differences, and there are no trends. Using the same formula, the competitiveness index of Malaysia is also presented. It can be seen that it is lower than Indonesia. This is because the export of Malaysia is lower, especially CPO. It is important to note that the index will be different if all the downstream products are included. We can conclude that the model can also be used as a comparison tool.

In this example, the coordination inputs are static. Ideally the coordination inputs are the function of $G$ from the previous period. If $G$ is not increasing then coordination inputs is changed. This is also the case with control inputs. The control inputs are functions of the outputs and coordination inputs. Control inputs are changed if the outputs are not as expected, or because there are changes in coordination inputs. The application of the model by choosing appropriate coordination inputs and control inputs, also its relation, are recommended for future research.

Table 2. CPO dan RPO export (ton)

\begin{tabular}{ccccccc}
\hline Year & $\begin{array}{c}\text { CPO export } \\
\text { (model) }\end{array}$ & $\begin{array}{c}\text { CPO export } \\
\text { (actual) }\end{array}$ & Error & $\begin{array}{c}\text { RPO export } \\
\text { (model) }\end{array}$ & RPO export (actual) & Error \\
\hline 2005 & 4105581.61 & 4565624.65 & -0.10 & 5108969.28 & 5810565.348 & -0.12 \\
2006 & 5037175.56 & 5199286.87 & -0.03 & 5564536.32 & 6901634.109 & -0.19 \\
2007 & 6308139.32 & 5701286.12 & +0.11 & 6020103.36 & 6174132.042 & -0.02 \\
2008 & 7583661.63 & 7904178.63 & -0.04 & 6475670.40 & 6386506.774 & +0.01 \\
2009 & 9020260.61 & 9566746.05 & -0.06 & 6931237.44 & 7262459.696 & -0.05 \\
2010 & 10648803.93 & 9444170.40 & +0.13 & 7386804.48 & 6847685.771 & +0.08 \\
\hline
\end{tabular}




\section{Conclusion}

The conceptual model of Indonesian palm oil industry is presented, describing the interaction of palm oil industry stakeholders, with competitiveness as the output. The model can explain how the government can give such a positive meso environment by giving policy and regulation that affect the chains so the industry competitiveness will increase, in an international economic environment which cannot be controlled. This model uses a hierarchical multilevel system approach. A simple numerical example is given using actual data on the Indonesian palm oil industry.

Further research is still needed in order to choose appropriate coordination inputs and control inputs, also the relation between them. The model also can be developed further downstream to the derivatives of palm oil, by expanding the model and the performance function. The model then can simulate the impact of the government policy and or regulation to the whole industry before its implementation.

\section{Acknowledgement}

We thank the anonymous reviewers for their helpful suggestions and ideas. In addition, part of this article was presented in 3rd LSCM, Bali, 26-28 June 2013.

\section{References}

1. Akyuwen, R., and Sulistyanto, A.I., The Dynamics of Crude Palm Oil Export, AFBE 2010 Conference Papers, ISSN 1905-8055, 2010, pp 1-40.

2. BPS, Badan Pusat Statistik, Statistik Kelapa Sawit Indonesia 2008, Katalog BPS: 5504003. 2009.

3. BPS, Badan Pusat Statistik, Produksi Perkebunan Besar Menurut Jenis Tanaman, 2010.

4. Belshaw, D.G.R., Bjorlo, T.J., Shah, M.M., A Hierarchical System Simulation of the Rural Development Process, Automatica, 11, 1975. pp 401-408.

5. Chalil, D., An Empirical Analysis of Asymmetric Duopoly in the Indonesian Crude Palm Oil Industry, Doctoral Thesis, Faculty of Agricultural, Food and Natural Resource, University of Sidney, New South Wales, Australia, 2008.

6. European Comission, European Competitiveness Report 2002. Competitiveness and Benchmarking, 2003.

7. Fagerberg, J., International Competitiveness, The Economic Journal, 98(391), 1988, pp. 355374.

8. Frohberg, K., and Hartmann, M., Comparing Measures of Competitivenes: Examples for Agriculture in the Central European Associates, Ins- titute of Agricultural Development in Central and Eastern Europe (IAMO), Discussion Paper No. 2., 1997.

9. Haimes, Y. Y., Hierarchical Modeling of Regional Total Water Resources Systems, Automation, 11, 1975, pp 25-36.

10. Haimes, Y. Y., and Li, D., Hierarchical Multiobjective Analysis for Large-scale Systems: Review and Current Status, Automatica, 24(1), 1988, pp. 53-69.

11. Hadiguna, R. A., Model Penilaian Risiko Berbasis Kinerja untuk Rantai Pasok Berkelanjutan di Indonesia, Jurnal Teknik Industri, 14(1), 2012, pp 13-24.

12. Hidayat, S., Marimin, Suryani, A., Sukardi, and Yani, M., Model Identifikasi Risiko dan Strategi Peningkatan Nilai Tambah pada Rantai Pasok Kelapa Sawit. Jurnal Teknik Industri, 14(2), 2012, pp 80-96.

13. Kaplinsky, R. and Morris, M., A Handbook for Value Chain Research, IDRC, 2001.

14. Marks, S. V., Larson, and Pomeroy, Economic Effects of Taxes on Exports of Palm Oil Products, Bulletin of Indonesian Economic Studies, 34(3), 1998, pp 37-58.

15. Martin, L., Westgren, R., and van Duren, E., Agribusiness Competitiveness across National Boundaries, AAEA Report, 1991.

16. Mesarovic, M.D., Macko, D., and Takahara, Y., Theory of Hierarchical, Multilevel Systems, Academic Press, New York \& London, 1970.

17. Porter, M. E., Competition in Global Industries, Harvard, Boston. 1986.

18. Porter, M. E., The Competitive Advantage of Nations, Free Press, New York, NY. 1990.

19. Rifin, A., Export Competitiveness of Indonesia's Palm Oil Product, Trends in Agricultural Economics, Asean Network for Scientific Information, 2009.

20. Rifin, A., The Effect of Export Tax on Indonesia's Crude Palm Oil (CPO) Export Competitiveness, Asean Economic Buletin, 27(2), 2010, pp 173184.

21. Sa'id, E. G., Review Kajian, Penelitian dan Pengembangan Agroindustri Strategis Nasional: Kelapa Sawit, Kakao dan Gambir, Jurnal Teknik Industri Pertanian, 19(1), 2009, pp 45-55.

22. Siggel, E., International Competitiveness and Comparative Advantage: A Survey and a Proposal for Measurement, Journal Industry Competition Trade, 6, 2006, 137-159.

23. Silitonga, R. Y. H., and NurBahagia, S., Usulan Framework Peningkatan Daya Saing Industri Minyak Kelapa Indonesia dengan Pendekatan Rantai Nilai, $6^{\text {th }}$ National Industrial Engineering Conference \& Workshop 2011, Ubaya, Surabaya. 2011. 
24. Simeh, M. A. Comparative Advantage of the European Rapeseed Industry vis-a-vis Other Oils and Fats Producers, Oil Palm Industry Economic Journal, 4(2), Malaysian Palm Oil Board, 2004.

25. Stoilov, T., and Stoilova, K., Non-iterative Co-ordination in Multilevel Systems, International Journal of Systems Science, 29(12), 1988, pp. 1393-1416.

26. Stoilova, K., Predictive Non-iterative Coordinations in Hierarchical Systems, Automation and Remote Control, 67(4), 2006, pp. 634-646.

27. Susila, W. R., Impacts of CPO -Export Tax on Several Aspects of Indonesian CPO Industry, Oil Palm Industry Economic Journal, 4(2), 2004, pp.1-13.
28. Tallec, F., and Bockel, L., Commodity Chain Annalysis: Constructing the Commodity Chain Functional Analysis and Flow Charts, Food and Agricultural Organization of the United Nations, FAO, 2005.

29. Tambunan, T., Indonesian Crude Palm Oil: Production, Export Performance and Competitiveness. Working Paper Series no. 8, Center for Industries and SME Studies, Faculty of Economics, University of Trisakti, 2006.

30. Widodo, K. H., Abdullah A., and Arbita K. P. D., System Supply Chain Crude-Palm-Oil Indonesia dengan Mempertimbangkan Aspek Economical Revenue, Social Welfare dan Environment, Jurnal Teknik Industri, 12(1), 2010, pp 47-54.

31. World Economic Forum, The Global Competitiveness Report 2010-2011, Geneva, Switzerland, 2010. 